\title{
22. SEDIMENTARY FACIES AND SEDIMENTOLOGY OF THE LATE QUATERNARY SANTA BARBARA BASIN, SITE 893'
}

\author{
Richard J. Behl ${ }^{2}$
}

\begin{abstract}
Distribution and character of sedimentary facies in a 196.5-m core from Ocean Drilling Program (ODP) Site 893 in Santa Barbara Basin (southern California) reflect global and regional controls during the latest Quaternary. Stratigraphic trends in grain size, sediment composition, sedimentary fabric, and degree of bioturbation record changes in oceanic deep-water circulation, climate, sea level, basin geometry, sediment sources, and transport pathways through the last two glacial and interglacial episodes ( 160 k.y.). The sedimentary sequence in Hole 893A is divided into six facies: four record varied levels of bottomwater oxygenation by the degree of bioturbation of primarily laminated olive-gray hemipelagic mud, whereas two reflect coarse- and fine-grained event deposition. Varved sediments typical of the Holocene Santa Barbara Basin compose only $21 \%$ of the entire latest Quaternary sequence.

An ultra-high-resolution record ( $<10$-yr sample spacing) of bottom-water oxygenation, as shown by the preservation or destruction of annual varves, reveals cyclic variation over decadal to Milankovitch time scales and apparently reflects the changing age and ventilation of Pacific Intermediate Waters. Over the past $\sim 75$ k.y., bioturbation and basin oxygenation correspond closely to glacial-interglacial oscillation, with warm intervals being oxygen-depleted and laminated and cold intervals being oxygenated and bioturbated. Preliminary results suggest a correlation between basin stratigraphy and deep-water circulation proxy records from elsewhere in the Pacific and Atlantic oceans, indicating that sediments of Santa Barbara Basin are a sensitive recorder of global and regional paleoceanographic and paleoclimatic change.
\end{abstract}

\section{INTRODUCTION}

For the past four decades, varved sediments from the central part of Santa Barbara Basin (SBB) of the Southern California Continental Borderland have yielded ultra-high-resolution paleoceanographic and paleoclimatic records based on variation in fish (sardine) abundances (Soutar, 1967; Soutar and Isaacs, 1969; Baumgartner et al., 1992), planktonic microfossils (Pisias 1978, 1979; Lange et al., 1987, 1990), pollen (Heusser, 1978), stable isotopes (Dunbar, 1983; Schimmelmann and Tegner, 1991), biomarkers (Lajat et al., 1990; Kennedy and Brassell, 1992), and varve thickness (Soutar and Crill, 1977). For a review of previous work in SBB, see Kennett, Baldauf, et al. (1994) or Lange et al. (in press). All these prior studies were derived from shallow-penetration box or piston cores, and were restricted to the Holocene (generally the last several hundred years). It remained unknown whether the bathymetric and oceanographic conditions required for preservation of the detailed, varved record were unique to the Holocene or typical of the entire late Quaternary.

To answer this question, two advanced hydraulic piston cores were obtained from near the basin center $\left(34^{\circ} 17.25^{\prime} \mathrm{N}, 120^{\circ} 02.2^{\prime} \mathrm{W}\right)$ (Fig. 1; Kennett, Baldauf, et al., 1994), recovering $196.5 \mathrm{~m}$ (Hole $893 \mathrm{~A}$ ) and $68.8 \mathrm{~m}$ (Hole 893B) of intermittently laminated upper Quaternary sediments. Micropaleontologic and stable isotope stratigraphy indicate that Hole 893A extends into oxygen isotope Stage 6, approximately $160 \mathrm{ka}$ (Kennett, this volume). Accelerator mass spectrometry (AMS) radiocarbon dates to approximately 28,000 calendar years before present were obtained from the upper $43 \mathrm{~m}$ (Ingram and Kennett, this volume), providing a high-resolution chronostratigraphy for the last glacial/interglacial transition. Correlation of the magnetic secular variation record (Kennett, Baldauf, et al., 1994) offers

'Kennett, J.P., Baldauf, J.G., and Lyle, M. (Eds.). 1995. Proc. ODP. Sci. Results. 146 (Pt. 2): College Station. TX (Ocean Drilling Program).

'Marine Science Institute and Department of Geological Sciences, University of California, Santa Barbara, CA 93106-6150, U.S.A.

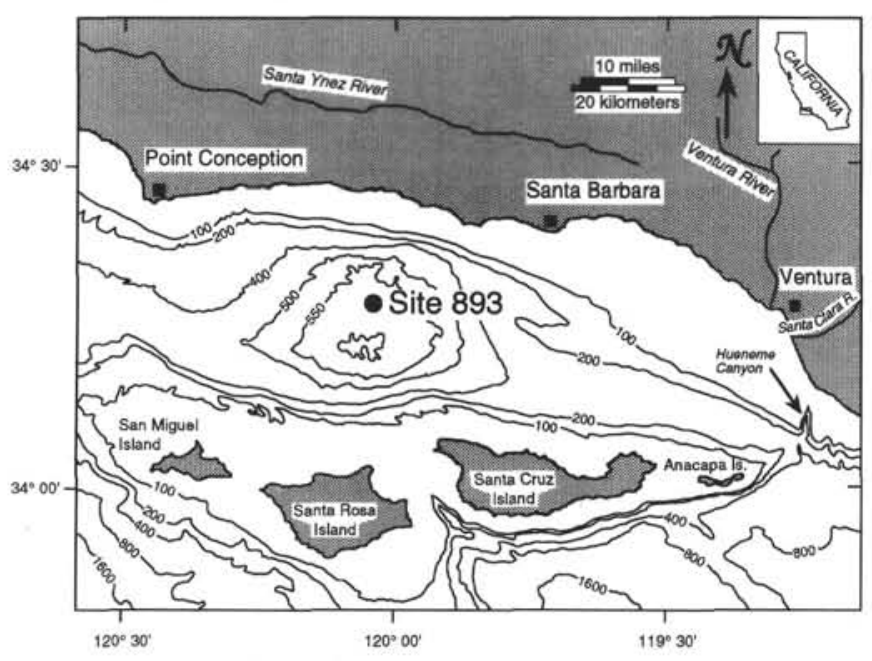

Figure 1. Bathymetric map and setting of Santa Barbara Basin and Site 893. Bathymetry in meters.

promise of extending the high-resolution chronostratigraphy beyond the range accessible by radiocarbon dating.

For the most part, the cored material was recovered in excellent condition except for irregularly distributed bedding-plane partings produced by degassing and expansion of the methane-rich sediment, contributing to a total recovery of $104 \%$ to $107 \%$ of the length of the cored sequence (Kennett, Baldauf, et al., 1994). The parting can interfere with some in-situ measurements of physical properties that require undisturbed fabrics over several centimeters, such as bulk density or magnetic susceptibility, however, it is not detrimental for most stratigraphic studies of a compositional nature or for samples specifically selected for microfabric analysis. All stratigraphic positions reported herein are corrected to account for the gaps formed by 
sediment degassing and are based on observations and analyses of the 196.5-m core from Hole 893A.

The high sedimentation rate $(\sim 120 \mathrm{~cm} / \mathrm{k} . \mathrm{y}$.), organic-rich varved mud, proximal setting recording both oceanic and continental signals, and the close relationship with the California Current system make Site 893 extremely important for paleoceanographic and paleoclimatic studies, many of which are presented in this volume (e.g., Kennett; Kennett and Ingram; Heusser). This paper presents the sedimentology and facies distribution of Hole 893A to provide a framework for paleoceanographic and paleoclimatic time series, and additionally explores the effects of paleoceanographic and paleoclimatic change on sedimentation in Santa Barbara Basin.

\section{SETTING OF THE MODERN SANTA BARBARA BASIN}

Santa Barbara Basin is the northernmost basin of the southern Californian Continental Borderland (Emery, 1960; Gorsline and Teng, 1989), bounded by the mainland on the north and the San Miguel-Anacapa island chain (known as the northern Channel Islands) to the south. The east-west-trending, 600-m-deep basin opens over a deep sill to the west ( $\sim 75 \mathrm{~m}$ depth) and a shallower sill to the east ( $\sim 230 \mathrm{~m}$ depth). Sediment supply to the basin is highly seasonal, with the bulk of siliciclastic sedimentation derived from riverine runoff during winter and early spring rainstorms (Soutar and Crill, 1977; Thornton, 1981, 1984). Consequently, planktonic sedimentation during the late spring, summer, and fall is largely undiluted by terrigenous material. Below sill depth, the modern basin contains oxygendepleted waters which derive from the upper part of the Pacific Intermediate Water mass and the Oxygen Minimum Zone (OMZ) off central California. Once within the basin, this low-oxygen water mass is further depleted of oxygen by degradation of organic matter from the highly productive surface waters, rendering the seafloor inhospitable to benthic faunas and preventing bioturbation (Emery and Hülsemann, 1962). In cores from the basin center (below $\sim 525 \mathrm{~m}$ water depth), the seasonal variations in sedimentation (siliciclastic-dominated vs. biogeneous-dominated) are preserved as thin, millimeterscale laminations, or varves. At the sediment-water interface, sulfatereducing, filamentous bacteria form extensive, stabilizing mats, below which continued bacterial oxidation of organic material renders shallow pore waters anoxic. Thickness of the varves correlates closely with historic and tree-ring records of precipitation (Schimmelmann and Tegner, 1991; Soutar and Crill, 1977). Although there is evidence for short-term (subseasonal) disruption of the basin's stratification (Sholkovitz and Gieskes, 1971; Reimers et al., 1990), suboxic conditions apparently prevail throughout most of the year, preserving primary laminations and other high-frequency paleoceanographic and paleoclimatic signals. In the last $2000 \mathrm{yr}$, only one episode of prolonged oxygenation of the basin floor is known to have occurred (Schimmelmann et al., 1992).

The spatial distribution of sedimentary fabrics throughout SBB is directly controlled by the dissolved oxygen content of the overlying bottom water (Savrda et al., 1984). In core-top samples, continuously laminated sediment occurs only in the central basin within the anaerobic zone where bottom waters contain $<0.1 \mathrm{~mL} / \mathrm{L}$ of dissolved oxygen $\left(\mathrm{O}_{2}\right)$. Fringing the laminated sediments is a narrow zone containing both varved and bioturbated layers, interbedded on a scale of centimeters; this facies lies beneath waters containing $\sim 0.1 \mathrm{~mL} / \mathrm{L}$ $\mathrm{O}_{2}$ and likely results from short-term fluctuation in the position of the dysaerobic-anaerobic boundary (at $0.1 \mathrm{~mL} / \mathrm{L} \mathrm{O}_{2}$ ). Completely massive (bioturbated) sediment occurs only beneath waters with $>0$. I$0.2 \mathrm{~mL} / \mathrm{L} \mathrm{O}_{2}$.

The modern SBB contains no significant active submarine fans or deltas to control sediment dispersal (Thornton, 1984). Instead, the basin is fed from three separate sources: (1) fine-grained siliciclastics chiefly derived from the Santa Clara and Ventura rivers as surface and mid-water suspensate plumes (Figs. 1 and 9; Drake et al., 1972; Fleischer, 1972; Thornton, 1981; Stein, this volume); (2) coarsegrained siliciclastic sediments transported eastward into the basin by coastal longshore drift (Trask, 1952; Emery, 1960), and then, in part, deflected seaward to the middle to outer shelf and returned to the west by strong bottom currents (Kolpack, 1986); and (3) biogenic components (e.g., diatoms, radiolarians, and foraminifers) derived from overlying surface waters and, in part, benthic organisms, chiefly foraminifers, echinoderms, and sponges. Slope deposits, covering $96 \%$ of the basin deeper that the shelf break, are redistributed by mass flows, including sediment creep, slides, and slumps (Thornton, 1984). Short-term deployment of sediment traps suggests that most of the flux to the sediment can be accounted for by biopackaging, either as fecal pellets (Dunbar and Berger, 1981) or marine snow (Alldredge and Gottschalk, 1989).

\section{METHODS}

Sedimentologic and stratigraphic observations for this study were made from three distinct data sets. The stratigraphic distribution of facies was determined by a detailed visual examination of the 196.5$\mathrm{m}$ core from Hole $893 \mathrm{~A}$, locally supplemented by examination of Xradiographs. The face of the archive half of the split core was carefully scraped with a negatively charged blade to reveal details of even subtle or obscured sedimentary structures (Kennett, Baldauf, et al., 1994). Sedimentary facies were identified and logged at $0.5-\mathrm{cm}(<5-$ $\mathrm{yr}$ ) resolution (see data report; Behl, this volume). Although analysis of X-radiographs would allow more subtle features to be detected, only limited selected intervals of the core were imaged at Texas A\&M University and Scripps Institution of Oceanography.

Textural analysis of fine-grained sediments was performed using a SediGraph 5100. All samples were treated with $15 \% \mathrm{H}_{2} \mathrm{O}_{2}$ and $1 \%$ $\mathrm{HCl}$ to remove organic matter and carbonate, dispersed in $0.1 \%$ $\mathrm{Na}_{6}\left(\mathrm{PO}_{3}\right)_{6}$, sieved to remove the $>63-\mu \mathrm{m}$ fraction, then redispersed in $0.1 \% \mathrm{Na}_{6}\left(\mathrm{PO}_{3}\right)_{6}$ before analysis. The SediGraph uses attenuation of $\mathrm{X}$-rays to determine the settling rate of dispersed particles; therefore, it measures equivalent spherical sedimentation diameters (ESSD), rather than intercepted diameter of the particles, cross-sectional area, or volume. As these sediments were deposited in a marine environment controlled largely by hydrodynamic conditions, ESSD was selected as the most meaningful measurement of grain size. Most of the hemipelagic sediments have large fine-grained tails of grains smaller than can be reliably measured $(1 \mu \mathrm{m}$ or $10 \phi)$; therefore, particle sorting is calculated by the log quartile deviation (Krumbein and Pettijohn, 1938).

Compositional data were collected from smear slides of the $>63$ $\mu \mathrm{m}$ (sand-sized) fraction separated from fine-grained sediments prior to SediGraph measurement of grain size. This fraction typically makes up $<2 \%$ of the hemipelagic mud samples and defines a distinct compositional population from that of the silt and clay portion. At least 300 grains were counted during line-count transects of the slides with frequency presented in number \% of intersections (not weight \% or area \%). The samples were previously cleaned of organic matter and carbonate as described above; therefore, these data are presented on a carbonate-free basis. An additional measurement-the presence or absence of echinoderm spines-was made by Ingrid Hendy (UC Santa Barbara) on washed, disaggregated samples untreated for carbonate removal.

\section{SEDIMENTARY FACIES Observations}

With the exception of infrequent, thin sand layers, the SBB core is composed entirely of hemipelagic mud consisting of terrigenous silty clay to clayey silt $(80 \%-90 \%)$ with minor amounts (generally $<10 \%$ each) of diatoms and nannofossils (bulk smear-slide analysis 
A

Facies 1:

Well-laminated hemipelagic mud

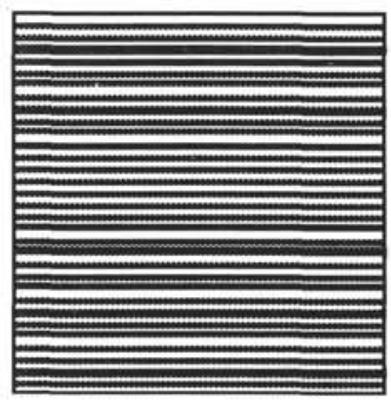

\section{B}

Facies 2:

Indistinctly laminated hemipelagic mud Trace-laminated hemipelagic mud

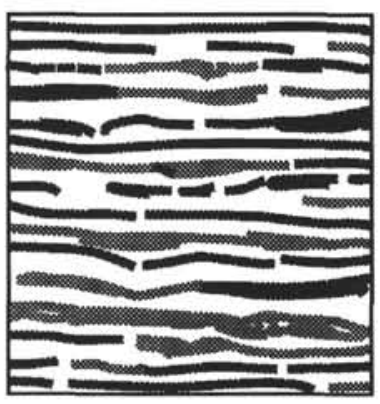

C

Facies 3:

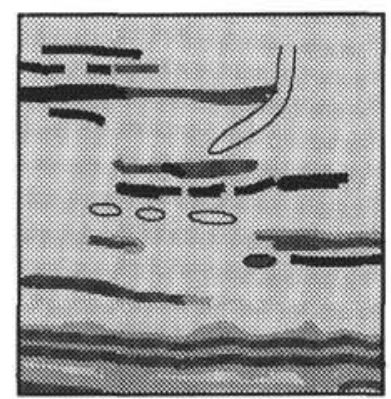

D

Facies 4:

Massive hemipelagic mud

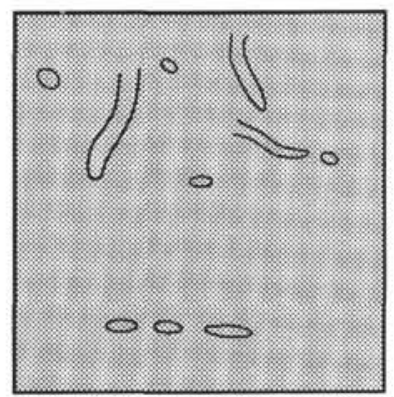

E

Facies 5: Gray-layer fine-grained event deposits

Homogeneous suspensate deposits

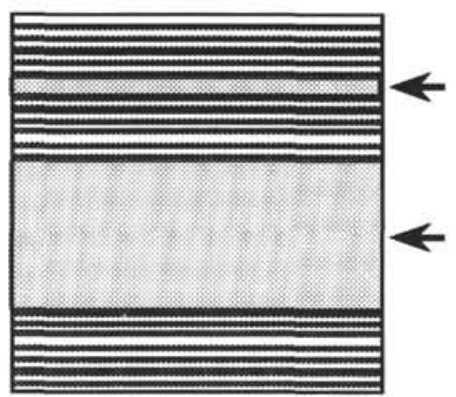

Graded clayey silt turbidites

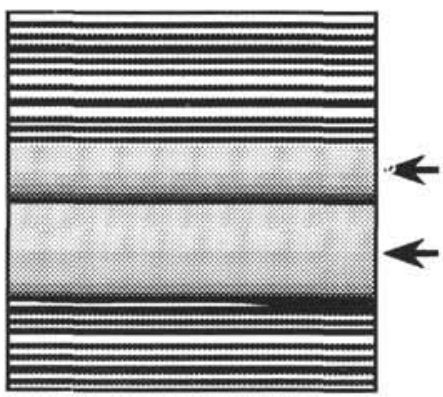

$\mathbf{F}$

Facies 6:

Sand turbidite

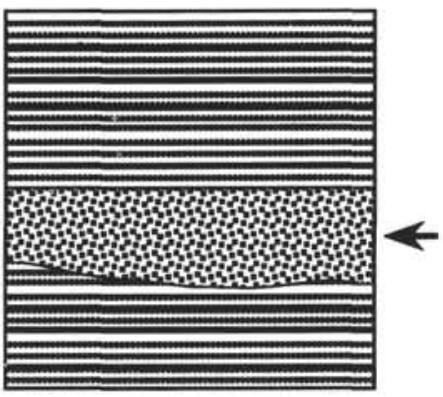

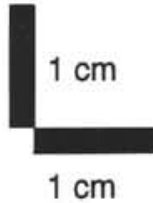

$1 \mathrm{~cm}$

Figure 2. Representations of characteristic features of sedimentary facies at Site 893. Graphic scale is approximate.

in Kennett, Baldauf, et al., 1994). Trace amounts ( $\leq 3 \%)$ of foraminifers, radiolarians, sponge spicules, echinoderm spines, and framboidal pyrite are consistently present in smear slides. Amorphous organic matter is present throughout most of the core (1-4 weight percent [wt\%] total organic carbon; see Gardner and Dartnell, this volume; Stein and Rack, this volume).

The sequence from Hole $893 \mathrm{~A}$ was described at a subcentimeter scale and six sedimentary facies are identified, including both hemipelagic and event deposits (Fig. 2). These facies are interbedded over a range of scales, from $<1 \mathrm{~cm}$ to $>2 \mathrm{~m}$.

Facies 1-4 define a gradual progression from well-laminated to massive (bioturbated) hemipelagic mud; all are chiefly olive-gray (5Y 4/2) with minor variation in value. The hemipelagic Facies 1-4 are all texturally similar, composed of 36 to $54 \mathrm{wt} \%$ silt ( $43 \%$ mean), with median grain sizes ranging from 2.2 to $5.5 \mu \mathrm{m}$ (Fig. 3). Sorting, as shown by the log quartile deviation, is very poor, ranging from 0.49 to 0.62 with a mean value of 0.53 .

Facies 1: well-laminated hemipelagic mud. Facies 1 is composed of unbioturbated, fine-grained sediment displaying distinct, continuous laminations across the central part of the core (Fig. 2A). Individual laminations are generally $<1.0$ to $2.0 \mathrm{~mm}$ thick and arranged as couplets of dark terrigenous-rich (winter) and light diatom-rich (spring-summer) layers (Soutar and Crill, 1977).

Facies 2: indistinctly laminated hemipelagic mud. Facies 2 is identified by the presence of diffuse, discontinuous or irregular laminations (Fig. 2B). Individual laminations are for the most part thicker than in Facies 1, typically ranging from 1.5 to $4 \mathrm{~mm}$ thick. Distinct burrows are extremely rare; when present they appear as 1- to 3-mmthick, structureless ellipses that are principally oriented in the horizontal direction (Chondrites?).

Facies 3: hemipelagic mud with traces of laminations. Facies 3 is identified by (a) olive-gray mud displaying extremely faint lamina- tions with diffuse stratigraphic contacts or by (b) an interval containing only a few discrete patches of laminations surrounded by homogeneous sediment (Fig. 2C). In addition to the homogenized regions, small, distinct 2- to 6-mm-diameter burrows (Chondrites?) are locally present. These are primarily expressed as elongate horizontal to inclined ellipses (up to $50^{\circ}$ from horizontal). The vertical extent of the burrows is typically $<1 \mathrm{~cm}$. Facies 2 and 3 locally contain "blooms" of benthic foraminifers in far greater abundance ( $>2$ tests/ $\mathrm{cm}^{2}$ visible on the scraped core face) than observed in Facies 1 . These blooms are most common in centimeter-thick layers located immediately above well-laminated sediment (Facies 1).

Facies 4: massive hemipelagic mud. Facies 4 is composed of olive-gray mud containing no discernible primary fabric. Lower boundaries of Facies 4 layers are locally discordant and irregular on a $<1$-centimeter scale. These massive intervals are commonly mottled by texture or color and locally display discrete burrows $3-10 \mathrm{~mm}$ thick and up to $30 \mathrm{~mm}$ long. These burrows are most visible at layer boundaries where strong contrasts in sediment color exist (Fig. 2D). Some burrows originating in massive layers show vertical branching and extend $1-3 \mathrm{~cm}$ in total length. Internal structure of the burrows is not clear when observed on the surface of the core.

Facies 5: gray layer deposits. Facies 5 is characterized by the distinct lack of olive coloration and a decided gray appearance (5Y 5/1). Gray layers typically have sharp bases and often display sharp tops. Gray layers are locally micaceous or silty, especially at their bases; many are normally graded in texture or in color (dark to light) while others are massive. Gray layers range from a few millimeters to 20 $\mathrm{cm}$ in thickness; some units are amalgamations of up to four distinct graded deposits. Although gray layers display a broader range of grain sizes than the hemipelagic facies ( 1.8 to $6.5 \mu \mathrm{m}$ median grain size, $29 \%$ to $60 \%$ silt), their mean values are similar $(3.2 \mu \mathrm{m}, 42 \%$ silt). Most gray layers are better sorted than the hemipelagic facies 


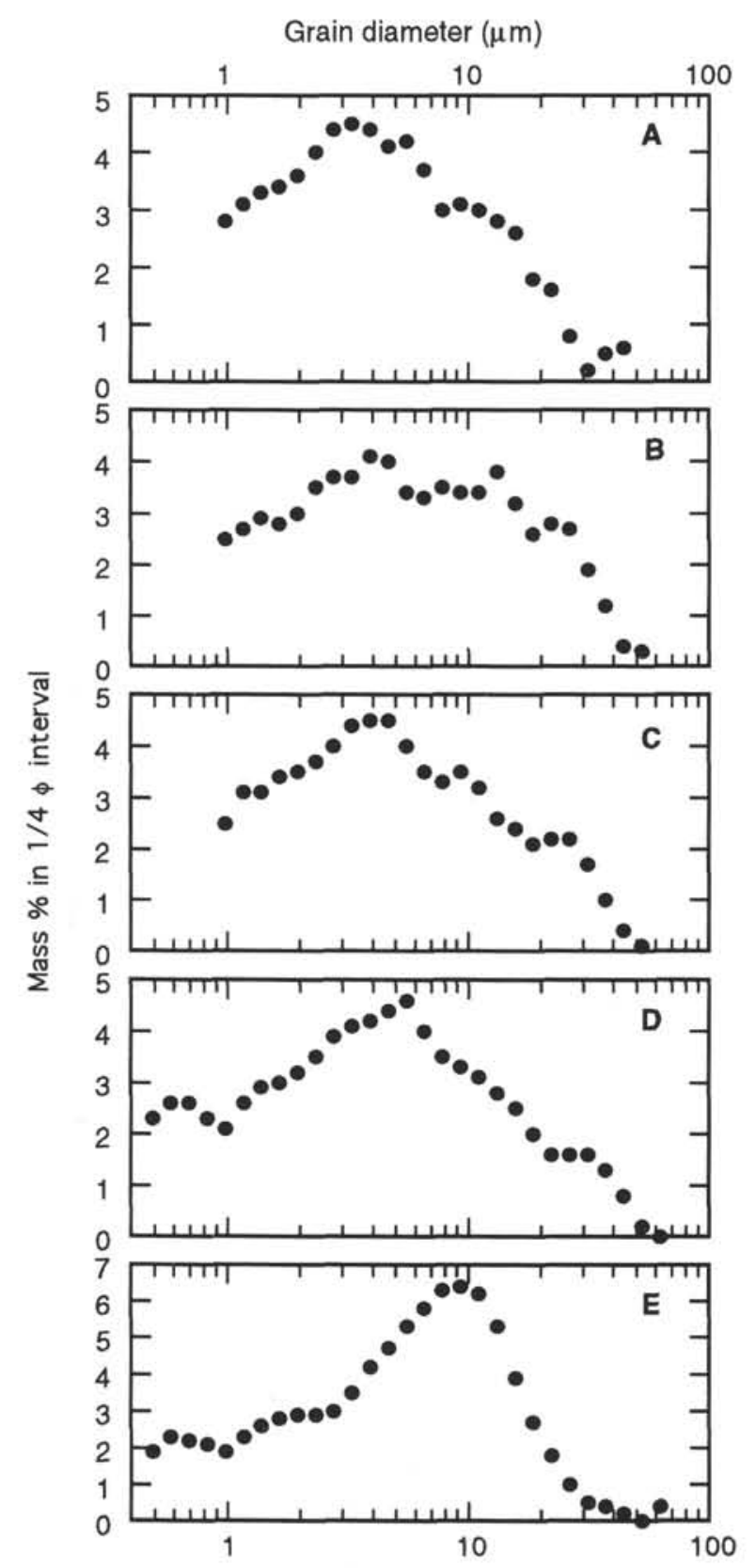

Figure 3. Representative grain-size spectra for Facies 1-5. A. Facies 1: welllaminated hemipelagic mud (Sample 146-893A-3H-6, 29-30 cm). B. Facies 2: indistinctly laminated hemipelagic mud (Sample 146-893 A-21 H-4, 29-30 $\mathrm{cm}$ ). C. Facies 3: hemipelagic mud with traces of laminations (Sample 146893A-14H-3, 29-30 cm). D. Facies 4: massive hemipelagic mud (Sample 146-893A-14H-7, 25-26 cm). E. Facies 5: gray layer event deposits (Sample 146-893A-3H-2, 24-25 cm). Note better sorting of (E) (event deposit) compared with (A-D) (hemipelagic mud facies). Vertical axes show mass percent in each $1 / 4 \phi$ interval.

( 0.45 to $0.51 \log$ quartile deviation, 0.48 mean) and their grain size distributions (i.e., narrow distribution with minor fine-grained tails) are typical of sediment that settled as individual particles according to Stoke's Law rather than as aggregates or flocs (Fig. 3E; Kranck, 1984).

Facies 6: sand deposits. Facies 6 is composed of very fine to finegrained quartzose to quartzofeldspathic sand (Marsaglia et al., this volume). The sand is unconsolidated and uncemented with individual deposits ranging from millimeters to $>2 \mathrm{~m}$ in thickness. The thicker beds are typically disturbed by the HPC coring process, yet some display normal size grading. Thinner deposits $(<2 \mathrm{~cm})$ are generally well-preserved, display sharp bases and locally show gradational or massive mud tops (Fig. 2F). A few sand layers are planar laminated.

\section{Facies Discussion}

In general, the diameter and depth of penetration of macrofaunal burrows correlates with the oxygenation level of overlying bottom waters (Pearson and Rosenberg, 1978; Savrda et al., 1984); that is, the greater the oxygenation, the greater and deeper the biological mixing. In this study, I assume that the relation between oxygen levels and burrow size extends to smaller, meiofaunal and microfaunal benthic organisms (e.g., foraminifers, nematodes, etc.) that are capable of sublamination-scale burrowing. The distinction between different lamination styles and degree of bioturbation in Facies 1-4 in this study serves as a "bioturbation index," which reflects the dissolved oxygen content of bottom water during or shortly after deposition (Byers, 1977; Savrda et al., 1984; Droser and Bottjer, 1986). In the modern central SBB, Savrda et al. (1984) found laminated sediments under anaerobic conditions $\left(<0.1 \mathrm{~mL} / \mathrm{L} \mathrm{O} \mathrm{O}_{2}\right)$, homogenized (bioturbated) sediments within dysaerobic or aerobic environments $\left(>0.1-0.2 \mathrm{~mL} / \mathrm{L} \mathrm{O}_{2}\right)$, and interbedded laminated and homogeneous sediment layers at the anaerobic-dysaerobic boundary. Some laminated sediments adjacent to the anaerobic-dysaerobic boundary display a few cross-cutting burrows, but most of the primary fabric is preserved. These relationships are the basis of the following interpretations:

Facies I (well-laminated hemipelagic mud) was clearly deposited within anaerobic conditions $\left(<0.1 \mathrm{~mL} / \mathrm{L} \mathrm{O}_{2}\right)$ that effectively excluded burrowing macrofauna capable of disturbing the fine primary lamination. Although distinct burrows are rare in Facies 2 (indistinctly laminated hemipelagic mud), it is reasonable that the diffuse and irregular laminations reflect a minor degree of microfaunal to meiofaunal bioturbation of the distinct varves of Facies 1. In Facies 2, the very small-scale bioturbation was only sufficient to broaden and disturb the primary laminations, but not sufficient to obliterate them.

Facies 3, containing small burrows and either (a) faint, broad, diffuse laminations or (b) isolated patches of laminated fabric surrounded by structureless mud, records an increased degree of infaunal mixing. Bioturbation was sufficient to homogenize part of the sediment (vertically or laterally), yet insufficient to obliterate evidence of the primary pattern of seasonal sedimentation. This facies was likely formed close to the anaerobic-dysaerobic boundary, which Savrda et al. (1984) place beneath waters containing approximately $0.1 \mathrm{~mL} / \mathrm{L}$ $\mathrm{O}_{2}$. In particular, Facies 3(b) probably resulted from temporal changes in bottom-water oxygenation in which originally laminated sediment was subsequently partially homogenized by downward penetration of burrows during an episode of oxygenation. The unusual blooms of benthic foraminifers that locally occur at the bases of Facies 2, 3 or 4 layers where found directly above well-laminated sediment (Facies 1) may reflect the sudden availability of previously ungrazed, organic matter-rich laminated sediments with regression of the anaerobic-dysaerobic boundary and the corresponding increase in the dissolved oxygen content of bottom water (see Savrda and Bottjer [1987] for a similar stratigraphic occurrence of shelled macrofauna in Miocene rocks).

Grimm et al. (unpubl. data) suggest that diffuse lamination, as found in Facies 3(a), may be a primary sedimentary feature reflecting lower seasonality than known for the late Holocene. It is unlikely, however, that hemipelagic sedimentation over tens to hundreds of years would remain only subtly changed in composition and texture from season-to-season and year-to-year, without any distinctive seasonal plankton blooms or rainfall run-off deposits. For this reason, I 


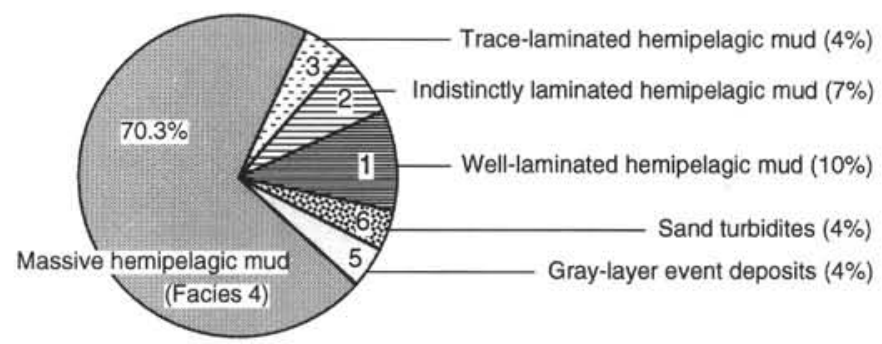

Figure 4. Pie chart showing relative stratigraphic abundances of sedimentary facies at Hole 893A.

find it less astonishing to assume that faint, diffuse laminations result from synsedimentary, millimeter-scale horizontal bioturbation of originally distinct seasonal laminations.

Due to the lack of primary structures and the presence of distinct burrows, and the gradational character of Facies 1 through 4, Facies 4 (massive olive gray mud) is considered to result from synsedimentary or postdepositional biological homogenization beneath waters with $>0.1-0.2 \mathrm{~mL} / \mathrm{L} \mathrm{O}_{2}$. Common mottling, distinct burrows, and the discordant and irregular character of the lower boundaries of many Facies 4 units attest to their origin by bioturbation. Complete homogenization generally mixes $<3 \mathrm{~cm}$ deep as indicated by the presence of numerous thin, massive layers intercalated between laminated intervals and by the maximum vertical extent of observed burrows. An undetermined portion of this massive facies, however, may be due to event deposition of remobilized slope sediment (Thornton, 1986) with texture and composition identical or indistinguishable from that of the basinal facies. Some redeposited sediment can be identified by subtle compositional grading or the presence of thin, mica-rich layers.

Gray layers (Facies 5) are moderately well sorted, commonly graded, sharp-based, and have a color and mineralogic composition that is distinct from the olive-green hemipelagic mud (Stein, this volume). Consequently, gray layers are interpreted as fine-grained event deposits. Thornton (1984) interpreted the massive and graded gray layers as flood suspensate deposits from major storms and graded "silty" turbidites, respectively. The sand deposits (Facies 6) are also sharp-based, locally graded and intercalated with fine-grained hemipelagic muds. They are interpreted as coarse-grained turbidites.

Overall, laminated hemipelagic mud (Facies I-3) makes up 21\% of the total stratigraphic thickness of the core, massive olive-gray mud (Facies 4 ) accounts for $70 \%$, and the event deposits (Facies 5 and 6) account for the remainder (approximately 4\% each) (Fig. 4). This percentage distribution of facies is markedly different from that previously reported from the Holocene section, which is composed of $70 \%$ laminated olive-gray mud, $4 \%$ massive olive-gray mud, and 26\% "gray layer" event deposits (Thornton, 1984). This distribution shows that anaerobic conditions responsible for preservation of laminated sediment in the Holocene SBB were typical of only a portion of the last 160 k.y.

\section{STRATIGRAPHIC TRENDS}

\section{Facies and Textural Trends}

\section{Hemipelagic mud}

The shore-based scientific party (Kennett, Baldauf, et al., 1994) initially defined six lithostratigraphic subunits based on the largescale distribution of laminated sediments (Fig. 5); these units have been placed in a chronostratigraphic framework by $\mathrm{AMS}{ }^{14} \mathrm{C}$ dating and oxygen isotope stratigraphy (Ingram and Kennett, this volume; Kennett, this volume). The lithostratigraphic subunits include: (IF) a lower intermittently laminated sequence corresponding to the latter

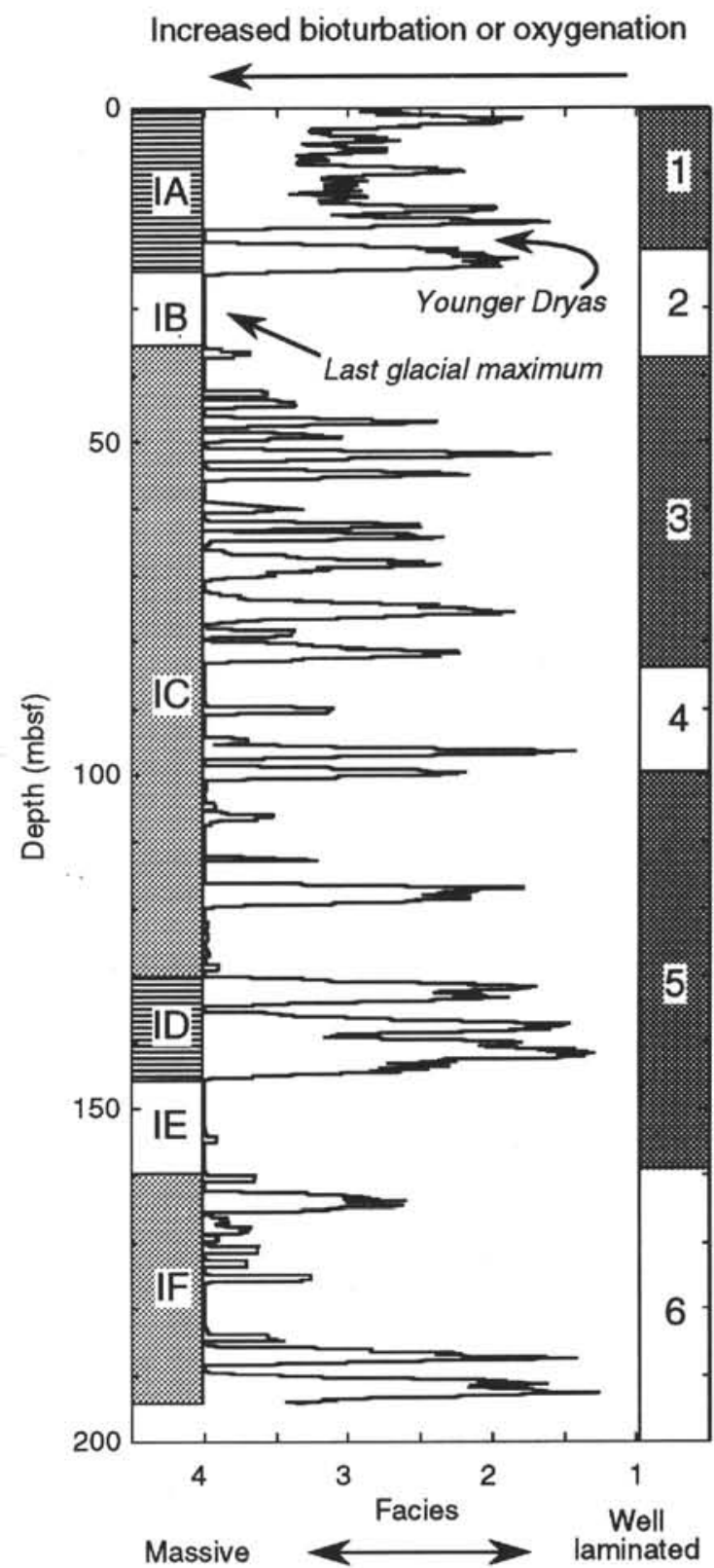

Figure 5. Degree of bioturbation ("bioturbation index") shown as a $99-\mathrm{cm}$ running average of $1-\mathrm{cm}$ observations vs. corrected depth downcore. Major lithostratigraphic subunits are presented at left (after Kennett, Baldauf, et al. 1994); Oxygen isotope stages presented at right (Kennett, this volume).

part of oxygen isotope Stage 6 (OIS 6); (IE) a lower nonlaminated sequence corresponding to Termination II and OIS 5e (Eemian); (ID) a lower laminated sequence corresponding to OIS $5 \mathrm{e}$ to $5 \mathrm{c}$; (IC) a thick upper intermittently laminated sequence spanning OIS $5 \mathrm{c}$ through OIS 3 ; (IB) an upper nonlaminated sequence corresponding to OIS 2; and (IA) an upper laminated sequence which correlates with most of Termination I and OIS 1 . In the upper $100 \mathrm{~m}$ (last 75 k.y.) the broad pattern of laminations is largely synchronized with glacial-interglacial changes (Fig. 6), with laminated sediments associated with warm intervals and massive sediments with cool to cold intervals (see Kennett, this volume, and Kennett and Ingram, this volume). This correlation between SBB laminations and the glacial-interglacial record breaks for the lower half of the core, suggesting that the interaction 


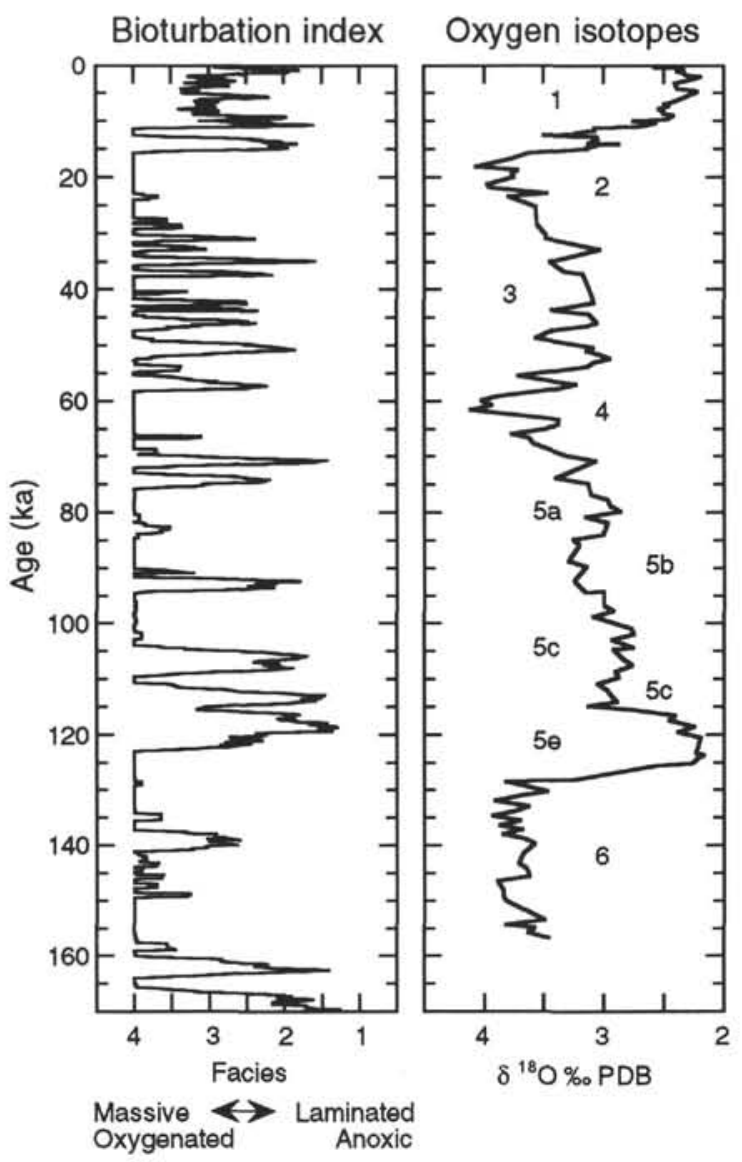

Figure 6. Comparison between the bioturbation index and the oxygen isotope stratigraphy (after Kennett, this volume). Note close correlation of laminated (oxygen depleted) intervals with warm stages and interstadials (OIS I, 3 , parts of 5) and massive (oxygenated) intervals with cold stages and stadials (OIS 2 and 4 ) since $\sim 75 \mathrm{ka}$.

between the SBB configuration and the oceanic circulation system must have been different prior to OIS 4 .

A more detailed and complex history of SBB bottom-water oxygenation is recorded by the fine-scale variation in the lamination and degree of bioturbation of the hemipelagic mud. Rather than simply switching from laminated to nonlaminated modes for extended periods of time, the degree of bioturbation varies on a variety of scales from centimeters to tens of meters, representing environmental change over decades to millennium (Fig. 7). In general, the lamination data or "bioturbation index" is presented as the $99 \mathrm{~cm}(\sim 800 \mathrm{yr})$ running average of the centimeter-resolution raw data to emphasize the major features of the record. For example, the interval from 30 to $60 \mathrm{ka}$ (roughly corresponding to OIS 3 ) displays an interval of intermittent lamination designated as the upper part of lithostratigraphic Subunit IC. On closer examination, the sediments record $>12$ distinct intervals of lamination (oxygen-depletion), each lasting $\sim 1000 \mathrm{yr}$. At a finer scale, these intervals are shown to be composed of numerous oscillations between oxygenated and dysaerobic conditions at periods $<100$ yr (Fig. 7).

\section{Gray Layers}

Gray layer event deposits are chiefly restricted to stratigraphic intervals that are laminated (Fig. 8). This relationship suggests that detectable occurrences of gray layers are largely controlled by preservation due to the lack of bioturbation. This is not surprising, as most gray layers are $0.5-2 \mathrm{~cm}$ thick and bioturbation within massive intervals probably mixes intervals as large as $3 \mathrm{~cm}$ thick. Gray layers that do occur within otherwise massive sequences are thicker and generally have diffuse, gradational tops and, locally, gradational bases. In some locations, a subtle graying of massive olive-gray mud is the only remaining indication of a bioturbated gray layer. Digital color analysis quantitatively records this color shift (Merrill and Beck, this volume), and integration of the deviation from the mean value for the massive hemipelagic mud may allow quantification of the volumetric contribution of gray event deposits, even in heavily bioturbated sediments.

Herein, the stratigraphic distribution of gray layers is plotted in Figure 8 as the running average of their percent thickness (i.e., centimeters of gray layers/meter of core). In addition to the association with laminated intervals, gray layers are most frequent during periods of relatively high sea level, for example, throughout OIS 5 (Fig. 8). This relationship suggests that deposition of even the clearly turbiditic deposits are related to major flood events or other changes in sediment supply rather than to off-shelf transport during sea-level falls. As basinal SBB sediments are chiefly derived from the Santa Clara and Ventura rivers at the eastern boundary of the depocenter (Fleischer, 1972; Thornton, 1981, 1984; Stein, this volume; Marsaglia et al., this volume), the highstand predominance of gray layers likely reflects the effect of changing basin geometry on the transport of flood suspensates (Fig. 9). With falling sea level, the eastern passage into the basin narrowed, reducing the transport of fine-grained suspensates into the basin from the Santa Clara and Ventura rivers. Transport of flood-related sediment into SBB may have taken significantly longer at lower sea levels than the $\sim 2 \mathrm{yr}$ required for flood deposits to be completely deposited in the central basin during the recent times (Drake et al., 1972). Slower or diminished transport would spread out the climatic signal to such a degree that the input pulse might be "washed out" by typical hemipelagic sedimentation. Decreased flux into the basin at lowstands did not result in decreased sediment accumulation rates (Gardner and Dartnell; Stein, both this volume) because the total depositional area of the basin was simultaneously reduced (Fig. 10).

Although earthquakes may trigger resuspension and redeposition of slope sediments in this seismically active region, the distinct composition of gray layers (Fleischer, 1972; Stein, this volume) indicates a unique provenance (i.e., floods from the Santa Clara/Ventura rivers) rather than simple reworking of typical hemipelagic slope sediment.

\section{Sand Turbidites}

Sand turbidites are largely restricted to two intervals, 107-115 mbsf ( $90-82 \mathrm{ka}$, OIS 5 b) and 50-70 mbsf ( 48-33, OIS 3) (Fig. 8). These sequences were chiefly deposited during intermediate eustatic levels, when sea level was $70-90 \mathrm{~m}$ below that at present, (Bard et al. 1990) when the shelf area was sharply reduced in size. The thickest sand bed at Site 893 was deposited during the minor sea-level drop from OIS $5 \mathrm{c}$ to $5 \mathrm{~b}$ when sea level was $\sim 20 \mathrm{~m}$ below that at present. The stratigraphic distribution of sand turbidites is plotted as the running average of their percent thickness (i.e., centimeter of sand/meter of core).

\section{Grain Size}

Stratigraphic variation in the grain size of hemipelagic mud (Facies 1-4) is presented as weight \% silt (Fig. 8). There is much sampleto-sample variation that does not correlate with sedimentary facies or lithostratigraphic unit. Grain size variation appears to have been most sensitive, however, to rates of sea-level change. Intervals of low percentages of silt at $\sim 165-150 \mathrm{mbsf}$ and $20-10 \mathrm{mbsf}$ are associated with rapid sea-level rises at Terminations II and I, respectively. Intervals of high percentages of silt are less well correlated with sea-level lowering at OIS transitions $5 \mathrm{e}$ to $\mathrm{d}$ and $5 \mathrm{a}$ to 4 . 
A

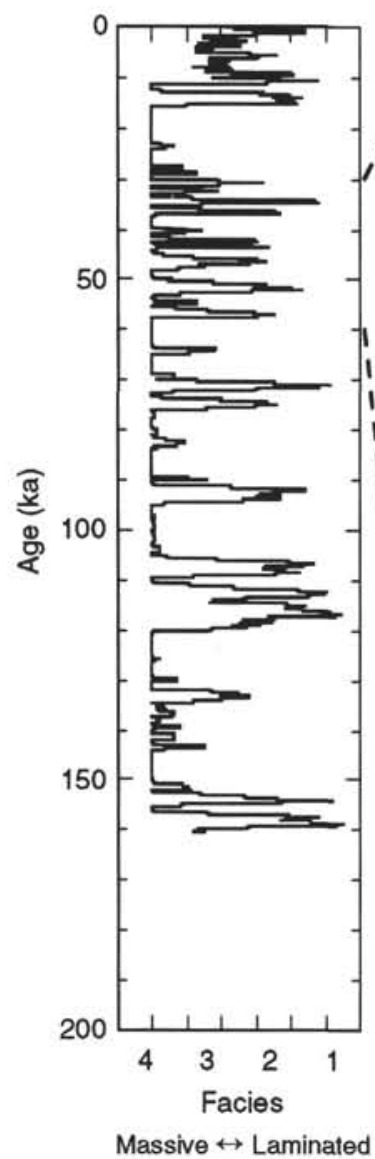

B

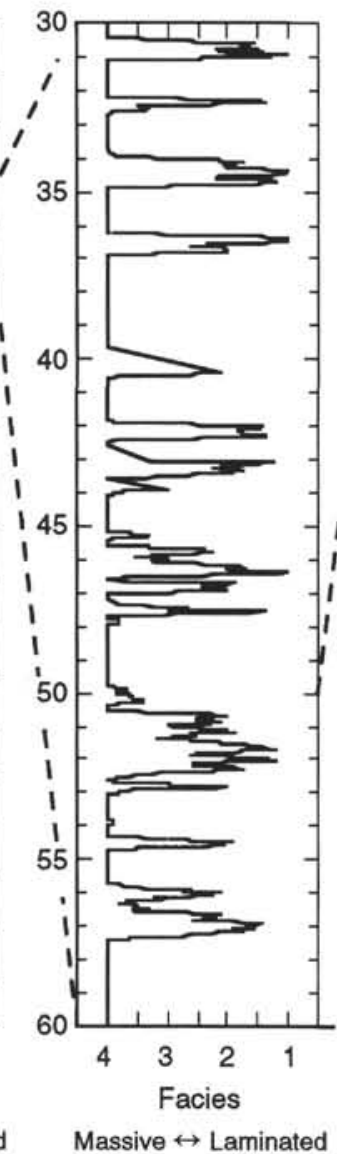

C

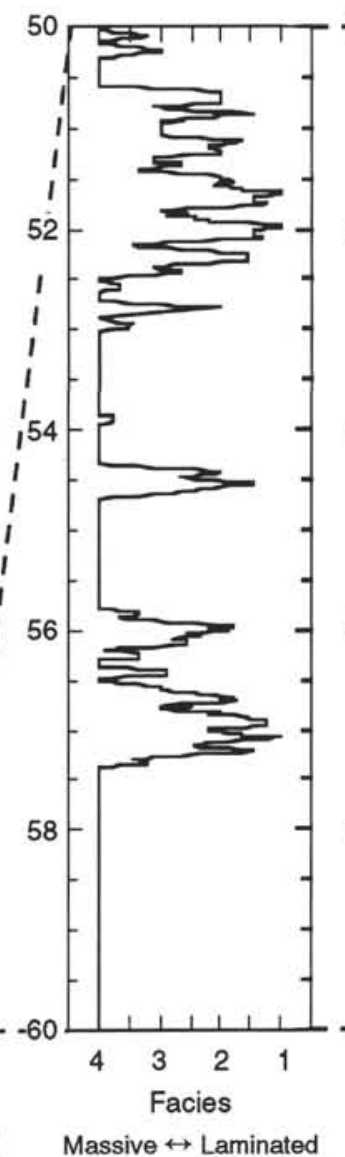

D

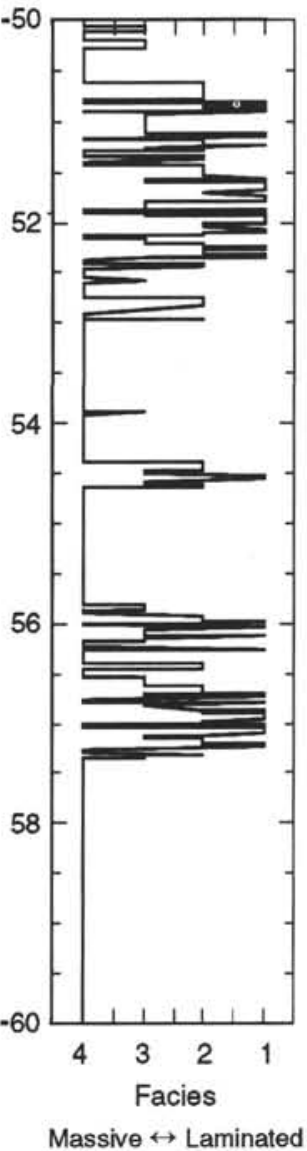

Figure 7. Bioturbation index vs. age presented at a number of scales and degrees of smoothing. Major intervals of preserved lamination (i.e., oxygen-depletion and nonbioturbation) are shown to consist of many, higher frequency oscillations between laminated and massive intervals. A. 99-cm running average. B. 19$\mathrm{cm}$ running average. C. $9-\mathrm{cm}$ running average. D. 1-cm raw data.

Thornton (1984) studied modern core-top sediments in SBB and found a decreasing trend in percentage of silt toward the center of the basin from the major sources at the basin's margins. The stratigraphic trends of grain size at Hole 893A do not reflect the changing proximity of the source areas as modulated by changing sea level. Instead, grain size must be controlled by the efficient transport of the siltsized fraction across the shelf into the deep basin center and the selective transport of certain compositional fractions (e.g., mica flakes) as outlined below.

\section{Compositional Trends}

Compositional data discussed here are derived from line counts of smear slides of the carbonate-free, sand-sized fraction of the hemipelagic mud (Facies 1-4). Only 25 samples have been counted and these data must be considered very preliminary. Nevertheless, the data suggest that several components of the $>63-\mu \mathrm{m}$ fraction may be useful proxies for change in sea level or environmental conditions. Total siliciclastics (i.e., quartz, feldspar, mica, and rock fragments) are the most common component, making up 30\%-98\% of the samples, averaging $69 \%$; mica alone accounts for $8 \%-42 \%$ of the total samples (25\% mean). Sponge spicules compose $1 \%-51 \%$ of the sample ( $21 \%$ mean), whereas siliceous plankton (diatoms, radiolarians, silicoflagellates) make up $<1 \%-39 \%$ of the total carbonate-free sample $(8.5 \%$ mean). Presence or absence of echinoid spines was determined on separate samples that still contained carbonate material (I. Hendy, unpubl. data).
Figure 11 presents the stratigraphic variation in abundance of siliceous plankton, mica, sponge spicules, and total siliciclastic grains compared to oxygen isotopes as a proxy for eustatic sea level. The abundance of siliceous plankton was apparently influenced by sealevel fluctuations with peak abundances occurring at 150,60, and 5 mbsf, corresponding to eustatic highstands during OIS $5 \mathrm{e}, 3$ and $\mathrm{I}$. The influence of sea-level variation is also partially reflected in the abundance of mica flakes, especially in the lower portion of the core where three peaks correlate with sea-level highstands at OIS 5e, $5 \mathrm{c}$, and 5a. The abundances of sponge spicules and total siliciclastic grains are inversely related because the two components generally make up $85 \%-98 \%$ of the samples. There is little direct correlation between variation in the abundances of these components and sea level or other environmental indicators except that sponge spicules are most abundant between 140 and $90 \mathrm{mbsf}$ and $10-0 \mathrm{mbsf}$, intervals that correspond to the general highstands of OIS 5 and 1. These increases during highstands may reflect either decreased transport of sand off the shelf or increased production of sponge spicules when shelf area expanded.

Figure 12 compares the presence and absence of macrofaunal debris-echinoid spines and sponge spicules - with the "bioturbation index" and the oxygen isotope record. The presence of echinoid spines in the hemipelagic mud is directly correlated with the absence of laminations, indicating that the spines were derived from echinoderms that actually occupied the oxygenated basin floor, rather than being transported downslope from shallower waters. Echinoderms are only present in the modern $\mathrm{SBB}$ in waters with $>\sim 0.3 \mathrm{~mL} / \mathrm{L} \mathrm{O}_{2}$ 


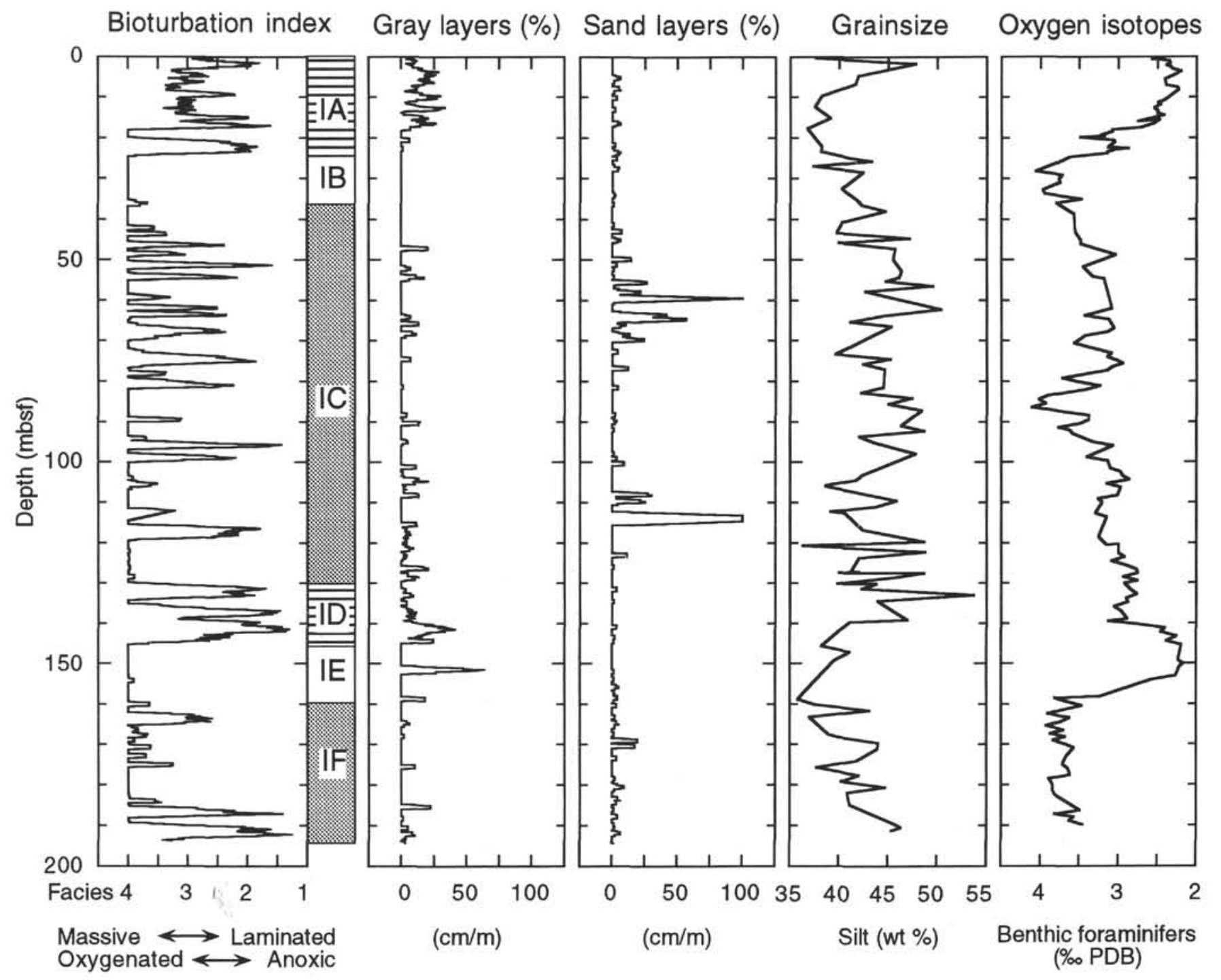

Figure 8. Stratigraphic distribution of bioturbation index, and percentages of gray layers (Facies 5), sand layers (Facies 6), and silt in the hemipelagic mud facies, compared with oxygen isotopes (after Kennett, this volume). The oxygen isotopes of benthic foraminifers are presented here as a proxy signal for sea level.

(interpreted from Savrda et al., 1984). Sponge spicules show no similar relation to laminations and ancient oxygen levels, but instead are weakly correlated with changes in sea level as described above, suggesting that they are chiefly allochthonous sediments transported to the central basin from the upper slope and shelf.

\section{DISCUSSION}

\section{Paleoceanographic Controls of Sedimentation}

The sediment of SBB is clearly a sensitive recorder of paleoceanographic and paleoclimatic change (e.g., Pisias, 1978, 1979; Dunbar, 1983; Baumgartner et al., 1992; Kennett, this volume). As detailed above, changing levels of bottom water oxygenation (from $<0.1 \mathrm{~mL} /$ $\mathrm{L} \mathrm{O}_{2}$ to $>0.3 \mathrm{~mL} / \mathrm{L} \mathrm{O}_{2}$ ) are shown by the degree of bioturbation of hemipelagic Facies 1-4. This "bioturbation index" varies sharply and cyclically over a range of time scales from subdecadal to that of the Milankovitch band (Fig. 7). Episodes of basin oxygenation or oxygen-depletion apparently reflect both regional and global influences. For example, laminations are absent or infrequent in sediments de- posited during the glacial maxima (OIS 2, 4, and portions of 6). Although a maximum glacio-eustatic lowering of sea level $\sim 120 \mathrm{~m}$ would drop the present $\mathrm{OMZ}$ sufficiently to prevent oxygen-depleted waters from entering the SBB, oxygen levels in SBB have varied significantly without major sea-level change. The oxygen content of SBB appears to most strongly reflect global to regional changes in deep- and intermediate-water circulation (Fig. 13). Perhaps the clearest example of supra-regional control of oxygenation of the SBB is found at the Younger Dryas cooling event $(\sim 13-11 \mathrm{ka})$. The laminated mud sequence deposited under anaerobic conditions since the last deglaciation is interrupted from 17.5 to $20.5 \mathrm{mbsf}$ by a massive interval of bioturbated sediment deposited during the Younger Dryas (Figs. 5 and 6; see also Kennett and Ingram, this volume). This stratigraphic pattern in the silled SBB is nearly identical to that observed in the open slope environment at DSDP Site 480 in the Gulf of California (Keigwin and Jones, 1990). There was no significant sea-level drop at this time (merely a pause in sea-level rise) to affect the positions of water masses entering the SBB. Furthermore, with the same signal recorded in different locations $>1000 \mathrm{~km}$ apart, this oxygenation event likely reflects the increased ventilation (and freshening) 
A

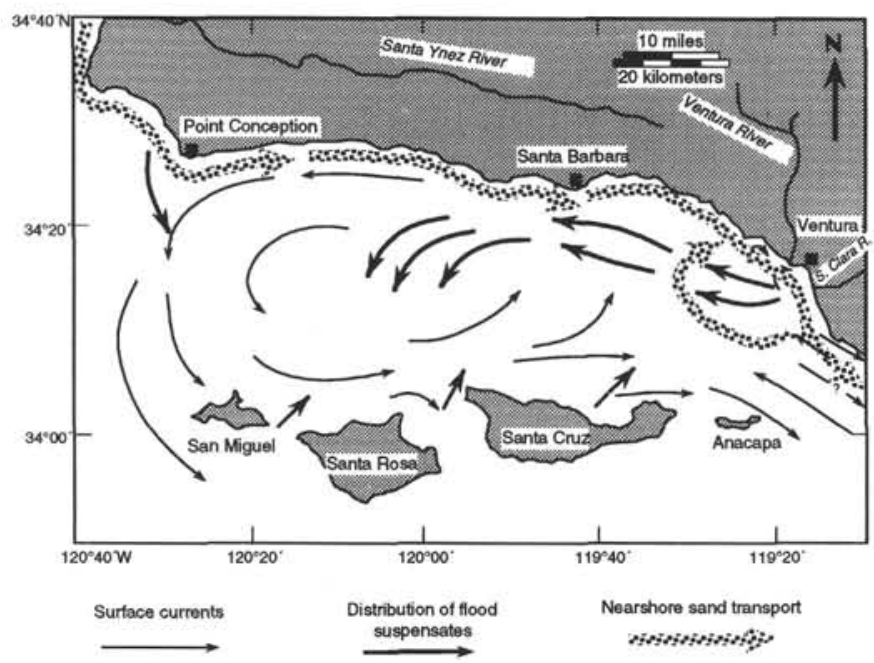

B

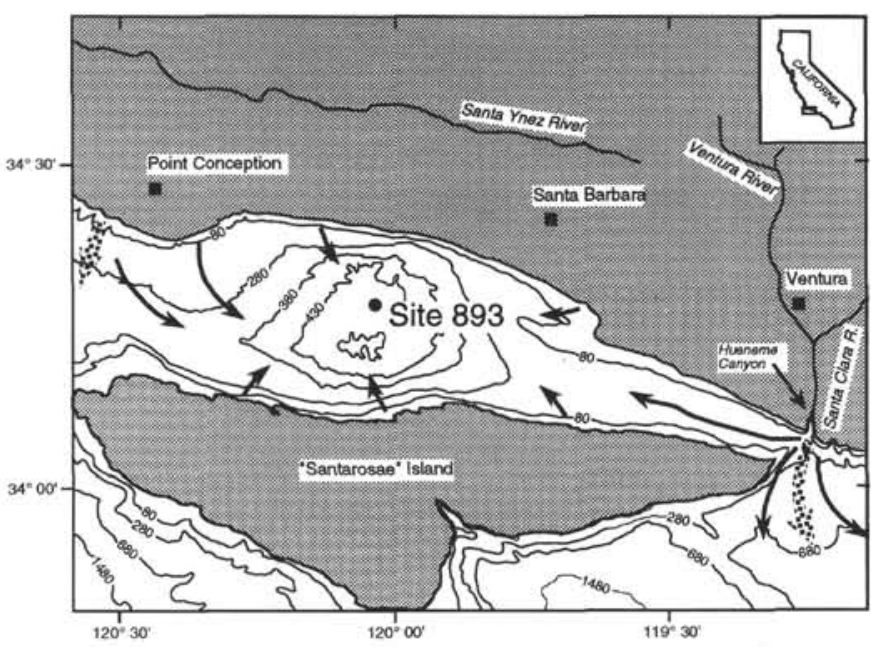

of intermediate water along the eastern Pacific rather than a local bathymetrically influenced signal. Indication of a wider-globalcontrol of oxygenation in SBB comes from the approximately dozen intervals of preserved lamination (i.e., oxygen-depletion) recorded during OIS 3 (Fig. 6). These events closely correspond in spacing to the subtle peaks in the stacked deep-sea oxygen isotope record presented by Martinson et al. (1987) as well as to the oxygen isotope record at Site 893 (Kennett, this volume). They have an even more startling correlation to the warm interstadials (Dansgaard-Oeschger events) recorded in the oxygen isotope record of the Greenland ice cores (Dansgaard et al., 1993). Variations in the carbonate composition of piston cores from the North Atlantic likewise show similar number and spacing of pulses in OIS 3 (Keigwin and Jones, 1994). Direct correspondence between these records links exceedingly rapid switches in climate and deep- and intermediate-water circulation across the globe to the oxygenation of SBB.

\section{Basin Geometry}

Variation in sea level has a dramatic effect on the geometry of the marginal SBB as shown by a comparison between the configuration of the modern basin and during the last glacial maximum (Figs. 1 and 9). The basin had approximately half the present depositional area at maximum lowstand (Fig. 10) which, with input fluxes held constant, would double linear sedimentation and mass accumulation rates. In-
Figure 9. A. Modern sediment transport pathways in Santa Barbara Basin. Modified from Kolpack (1971) and Thornton (1984). B. Lowstand (-12I m) configuration of the Santa Barbara Basin with speculative sediment transport paths.

creased sediment bypass of the SBB, however, had the inverse effect on sediment accumulation rates which remained relatively constant through high- and lowstands in SBB (see Gardner and Dartnell, and Stein and Rack, both this volume). The Santa Clara and Ventura rivers were probably captured by the Hueneme Canyon with most coarse-grained material shunted directly into the adjacent Santa Monica Basin (cf. Malouta et al., 1981). With falling sea level, the eastern passage into the basin shoaled and narrowed, reducing the flux of fine-grained suspensates into the basin. Furthermore, the lengthened Santa Clara-Ventura River system was restricted from significant westward migration into SBB by the presence of $>300 \mathrm{~m}$ highlands along the present coast (Fig. 9B). On the other side of the basin, longshore transport of sand from the west was intercepted by submarine canyons west of Point Conception (which currently head at $\sim 100 \mathrm{~m}$ water depth), routing most coarse-grained sediment away from SBB into the deep Arguello Canyon. The western sill likely shoaled above the depth of any potential oxygen-depleted water mass, and surface circulation was diminished with the coalescence of the northern Channel Island chain into one large sheltering landmass.

\section{CONCLUSIONS}

The distribution and character of sedimentary facies at Hole 893A was influenced by both global and regional paleoceanographic vari- 


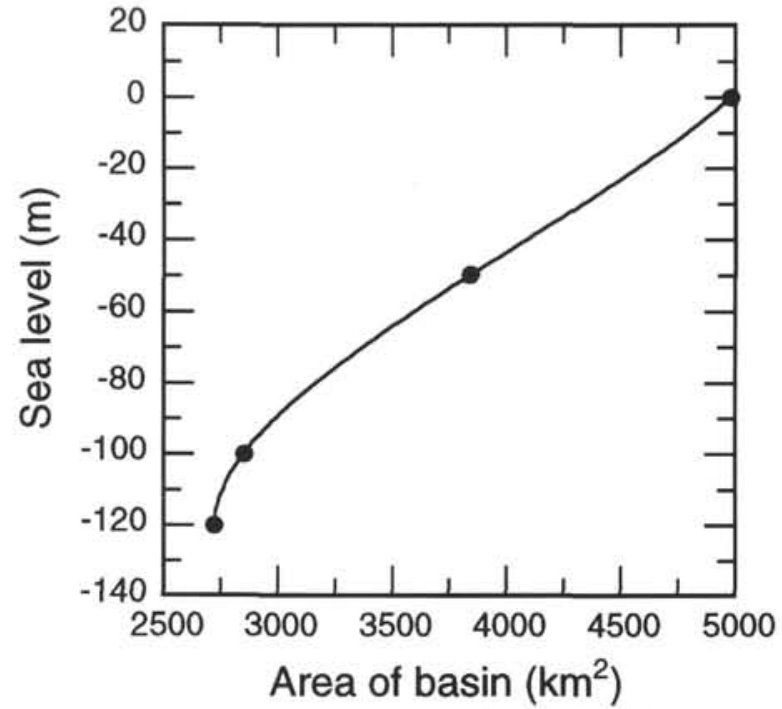

Figure 10. Variation of the total depositional area of Santa Barbara Basin with change in sea level constructed from present bathymetric contours.

ation. Stratigraphic trends in grain size and sediment composition were strongly influenced by effects of changing sea level on the depositional geometry of the basin, which controlled the width of the shelves, locations of sediment sources, sediment transport pathways, and selective transport of sedimentary components. Although the Holocene Santa Barbara Basin is well known for its varved sediments, the degree of bioturbation and preservation of laminations varied during the latest Quaternary, recording changes in the oxygenation level of the basin.

An ultra-high-resolution record ( $<10-\mathrm{yr}$ sample spacing) of bottom-water oxygenation ("bioturbation index") is constructed from the centimeter-scale distribution of facies in Santa Barbara Basin and displays cyclic variation over decadal to Milankovitch time scales. Correlation of this stratigraphy with paleoceanographic and paleoclimatic records elsewhere in the Pacific and Atlantic oceans suggests that oxygenation of Santa Barbara Basin reflects the changing age and ventilation of Pacific Intermediate Water rather than the local systematics of a marginal basin.

Specific findings of this study are:

1. The stratigraphy at Site 893 is defined by six sedimentary facies: well-laminated hemipelagic mud (Facies 1), indistinctly laminated hemipelagic mud (Facies 2), trace laminated hemipelagic mud (Facies 3), massive hemipelagic mud (Facies 4), gray-layer event deposits (Facies 5), and sand turbidites (Facies 6).

2. The Pleistocene distribution of sedimentary facies differs markedly from that of the Holocene, in which laminated sediments compose $>70 \%$ of the stratigraphic thickness. At Hole $893 \mathrm{~A}$, massive hemipelagic mud makes up $70 \%$ of the sequence, whereas all laminated muds (Facies 1-3) combine to compose only $21 \%$.

3. Increased sorting of gray layers (Facies 5) compared to the hemipelagic facies indicates that they settled chiefly as individual particles from suspended flows, rather than as aggregates in fecal pellets or marine snow.

4. For the past 75 k.y., the stratigraphic pattern of bioturbation (oxygenation) vs. lamination in SBB corresponds to glacialinterglacial oscillation in the global oxygen-isotope record, in which warm episodes were oxygen-depleted and laminated and colder episodes were oxygenated and massive.
5. Major intervals of lamination are composed of numerous smaller-scale cycles in the degree of bioturbation reflecting millennial to decadal variation in oxygen content of the basin.

6. Most sand transport to the basin center occurred at intermediate sea levels ( -70 to $-90 \mathrm{~m})$ and was chiefly limited to two pulses at 90 to $82 \mathrm{ka}$ (oxygen isotope Stage $5 \mathrm{~b}$ ) and 48 to 33 ka (oxygen isotope Stage 3).

7. Grain size of the hemipelagic facies, as shown by the percentage of silt, reflects eustatic variation in sea level, becoming finer during rapid transgressions at Terminations I and II, and coarser at transitions from oxygen isotope Stages 5e to $\mathrm{d}$ and from 5 a to 4 .

8. The composition of the sand-sized fraction of the hemipelagic mud is chiefly controlled by relative sea level. Siliceous plankton are more abundant (less diluted) at eustatic sea-level highstands. Mica flakes and sponge spicules were preferentially transported into the basin during periods of higher sea level.

9. The presence of echinoid spines in the sand-sized fraction of hemipelagic mud correlates with bioturbated intervals in Santa Barbara Basin, indicating that the massive sediment correlates with $>0.3 \mathrm{~mL} / \mathrm{L}$ of dissolved oxygen in the central basin.

\section{ACKNOWLEDGMENTS}

This research was supported by a postdoctoral fellowship from the Marine Science Institute, University of California at Santa Barbara. JOI/USSAC provided funds for travel to College Station, where the assistance of the Ocean Drilling Program Gulf Coast Repository staff was greatly appreciated. Echinoderm data were provided by Ingrid Hendy. Thanks to James P. Kennett for invigorating discussions and for providing useful criticism of this manuscript. This manuscript was greatly improved by the thoughtful reviews of Jack Baldauf, Chuck Savrda, and Scott Thornton-thank you.

\section{REFERENCES}

Alldredge. A.L., and Gottschalk, C.C.. 1989. Direct observation of the mass flocculation of diatom blooms: characteristic settling velocities and form of diatom aggregates. Deep-Sea Res., 36:159-171.

Bard, E., Hamelin, B., and Fairbanks, R.G., 1990. U-Th ages obtained by mass spectrometry in corals from Barbados: sea level during the past 130,000 years. Nature, 346:456-458.

Baumgartner, T.R., Soutar, A., and Ferreira-Bartrina, V., 1992. Reconstruction of the history of the Pacific sardine and northern anchovy populations over the past two millennia from sediments of the Santa Barbara basin, California. Calif. Coop. Oceanic Fisheries Invest. Rep., 33:24-40.

Byers, C.W., 1977. Biofacies patterns in euxinic basins: a general model. In Cook. H.E., and Enos, P. (Eds.). Deep-water Carbonate Environments. Spec. Publ.-Soc. Econ. Paleontol. Mineral., 25:5-17.

Dansgaard, W., Johnsen, S.J., Clausen, H.B., Dahl-Jensen, D., Gundestrup, N.S., Hammer, C.U., Hvidberg, C.S., Steffensen, J.P., Sveinbjörnsdottir, A.E., Jouzel, J., and Bond, G., 1993. Evidence for general instability of past climate from a 250-kyr ice-core record. Nature, 364:218-220.

Drake, D.E., Kolpack, R.L., and Fischer, P.J., 1972. Sediment transport on the Santa Barbara-Oxnard shelf, Santa Barbara Channel, California. In Swift, D.J.P., Duane, D.B., and Pilkey, O.H. (Eds.), Shelf Sediment Transport: Process and Pattern: Stroudsburg, PA (Dowden, Hutchinson, and Ross), 307-331.

Droser, M.L., and Bottjer, D.J., 1986. A semiquantitative field classification of ichnofabric. J. Sediment. Petrol., 56:558-559.

Dunbar, R.B., 1983. Stable isotope record of upwelling and climate from Santa Barbara Basin, California. In Thiede, J., and Suess, E. (Eds.), Coastal Upwelling, Its Sediment Record, Part B. Sedimentary Records of Ancient Coastal Upwelling: New York (Plenum), 217-246.

Dunbar, R.B., and Berger, W.H., 1981. Fecal pellet flux to modern bottom sediment of Santa Barbara basin (California) based on sediment trapping. Geol. Soc. Am. Bull., 92:212-218.

Emery, K.O., 1960. The Sea off Southern California: A Modern Habitat of Petroleum: New York (Wiley). 
Emery, K.O., and Hülsemann, J., 1962. The relationships of sediments, life and water in a marine basin. Deep-Sea Res. Part A, 8:165-180.

Fleischer, P., 1972. Mineralogy and sedimentation history, Santa Barbara Basin. California. J. Sediment. Petrol., 42:49-58.

Gorsline, D.S., and Teng, L.S.-Y., 1989. The California Continental Borderland. In Winterer, E.L., Hussong, D.M., and Decker, R.W. (Eds.), The Geology of North America (Vol. N): The Eastern Pacific Ocean and Hawaii. Boulder (Geol. Soc. Am.), 471-487.

Heusser, L., 1978. Pollen in Santa Barbara Basin, California: a 12,000 year record. Geol. Soc. Am. Bull., 89:673-678.

Keigwin. L.D., and Jones, G.A., 1990. Deglacial climatic oscillations in the Gulf of California. Paleoceanography, 5:1009-1023.

1994. Western North Atlantic evidence for millennial-scale changes in ocean circulation and climate. J. Geophys. Res., 99:1239712410 .

Kennedy, J.A., and Brassell, S.C.. 1992. Molecular records of twentieth century El-Niño events in laminated sediments from the Santa Barbara basin. Nature, 357:62-64.

Kennett, J.P., Baldauf, J.G., et al., 1994. Proc. ODP, Init. Repts., 146 (Pt. 2): College Station, TX (Ocean Drilling Program).

Kolpack, R.L., 1971. Oceanography of the Santa Barbara Channel. In Kolpack. R.L. (Ed.), Biological and Oceanographical Survey of the Santa Barbara Channel Oil Spill 1969-1970 (Vol. 2): Los Angeles (Allan Hancock Found., Univ. Southern Calif.), 90-180.

1986. Sedimentology of the mainland nearshore region of Santa Barbara Channel, California. In Knight, R.J., and McLean, J.R. (Eds.). Shelf Sands and Sandstones. Mem,-Can. Soc. Pet. Geol., II:57-72.

Kranck. K., 1984. Grain-size characteristics of turbidites. In Stow, D.A.V., and Piper, D.J.W. (Eds.), Fine-grained Sediments: Deep-water Processes and Facies: Geol. Soc. Spec. Publ. London, 15:83-92.

Krumbein, W.C., and Pettijohn, F.J., 1938. Manual of Sedimentary Petrography: New York (Appleton-Century-Crofts).

Lajat, M., Saliot, A., and Schimmelmann. A., 1990. Free and bound lipids in recent (1835-1987) sediments from Santa Barbara basin. Org. Geochem., 16:793-803.

Lange, C.B., Berger, W.H., Burke, S.K., Casey, R.E., Schimmelmann, A., Soutar, A., and Weinheimer. A.L., 1987. El Niño in Santa Barbara basin: diatom, radiolarian, and foraminiferan responses to the "1983 El Niño" event. Mar. Geol., 78:153-160.

Lange, C.B., Burke, S.K., and Berger, W.H., 1990. Biological production off southern California is linked to climatic change. Clim. Change, 16:319329.

Lange, C.B., Schimmelmann, A., Yasuda, M.K., and Berger, W.H., in press. Paleoclimatic significance of marine varves off southern California. In Wigand, P., and Rose. M. (Eds.), Southern California Climate: Trends and Extremes of the Past 2000 Years: Los Angeles (Los Angeles Co. Nat. Hist. Mus.).

Malouta, D.N., Gorsline, D.S., and Thornton, S.E., 1981. Processes and rates of Recent (Holocene) basin filling in an active transform margin: Santa Monica basin, California borderland. J. Sediment. Petrol., 51:1077-1095.

Martinson, D.G., Pisias, N.G., Hays, J.D., Imbrie, J., Moore, T.C., Jr., and Shackleton, N.J., 1987. Age dating and the orbital theory of the ice ages: development of a high-resolution 0 to 300,000 -year chronostratigraphy. Quat. Res., 27:1-29.
Pearson, T.H., and Rosenberg, R., 1978. Macrobenthic succession in relation to organic enrichment and pollution of the marine environment. Oceanogr. Mar. Biol., 16:229-311.

Pisias, N.G.. 1978. Paleoceanography of the Santa Barbara Basin during the last 8000 years. Quat. Res., 10:366-384.

1979. Model for paleoceanographic reconstructions of the California Current during the last 8000 years. Quat. Res., 11:373-386.

Reimers, C.E., Lange, C.B., Tabak, M., and Bernhard, J.M., 1990. Seasonal spillover and varve formation in the Santa Barbara Basin, California. Limnol. Oceanogr., 35:1577-1585.

Savrda, C.E., and Bottjer, D.J.. 1987. The exaerobic zone, a new oxygendeficient marine biofacies. Nature, 327:54-56.

Savrda, C.E., Bottjer, D.J., and Gorsline, D.S., 1984. Development of a comprehensive oxygen-deficient marine biofacies model: evidence from Santa Monica, San Pedro and Santa Barbara basins, California Continental Borderland. AAPG Bull., 68:1179-1192.

Schimmelmann, A., Lange, C.B., Berger, W.H., Simon, A., Burke, S.K., and Dunbar, R.B.. 1992. Extreme climatic conditions recorded in Santa Barbara Basin laminated sediments: the 1835-1840 Macoma event. Mar. Geol., 106:279-299.

Schimmelmann, A., and Tegner, M.J., 1991. Historical oceanographic events reflected in ${ }^{13} \mathrm{C} / 12 \mathrm{C}$ ratio of total organic carbon in Santa Barbara basin sediment. Global Biogeochem. Cycles, 5:173-188.

Sholkovitz, E.R., and Gieskes, J.M., 1971. A physical-chemical study of the flushing of the Santa Barbara Basin. Limnol. Oceanogr., 16:479-489.

Soutar, A., 1967. The accumulation of fish debris in certain California coastal sediments. Calif. Coop. Oceanic Fisheries Invest. Rep., 11:136139.

Soutar, A., and Crill, P.A., 1977. Sedimentation and climatic patterns in the Santa Barbara Basin during the 19th and 20th centuries. Geol. Soc. Am. Bull., 88:1161-1172.

Soutar, A., and Isaacs, J.D., 1969. History of fish populations inferred from fish scales in anaerobic sediments off California. Calif. Coop. Oceanic Fisheries Invest. Rep., 13:63-70.

Thornton, S.E., 1981. Suspended sediment transport in surface waters of the California Current off southern California: 1977-78 floods. Geo-Mar. Lett. 1:23-28.

1984. Basin model for hemipelagic sedimentation in a tectonically active continental margin: Santa Barbara Basin, California continental borderland. In Stow, D.A.V., and Piper, D.J.W. (Eds.), Finegrained Sediments: Deep-water Processes and Facies. Geol. Soc. Spec. Publ. London, 15:377-394.

1986. Origin of mass flow sedimentary structures in hemipelagic basin deposits: Santa Barbara basin, California Borderland. Geo-Mar. Lett., 6:15-19.

Trask, P.D., 1952. Source of beach sand at Santa Barbara. California as indicated by mineral grain studies. Univ. Calif. Tech. Rep. Eng., Ser. 14, no. 11.

Date of initial receipt: 8 September 1994

Date of acceptance: 3 April 1995

Ms 146SR-276 


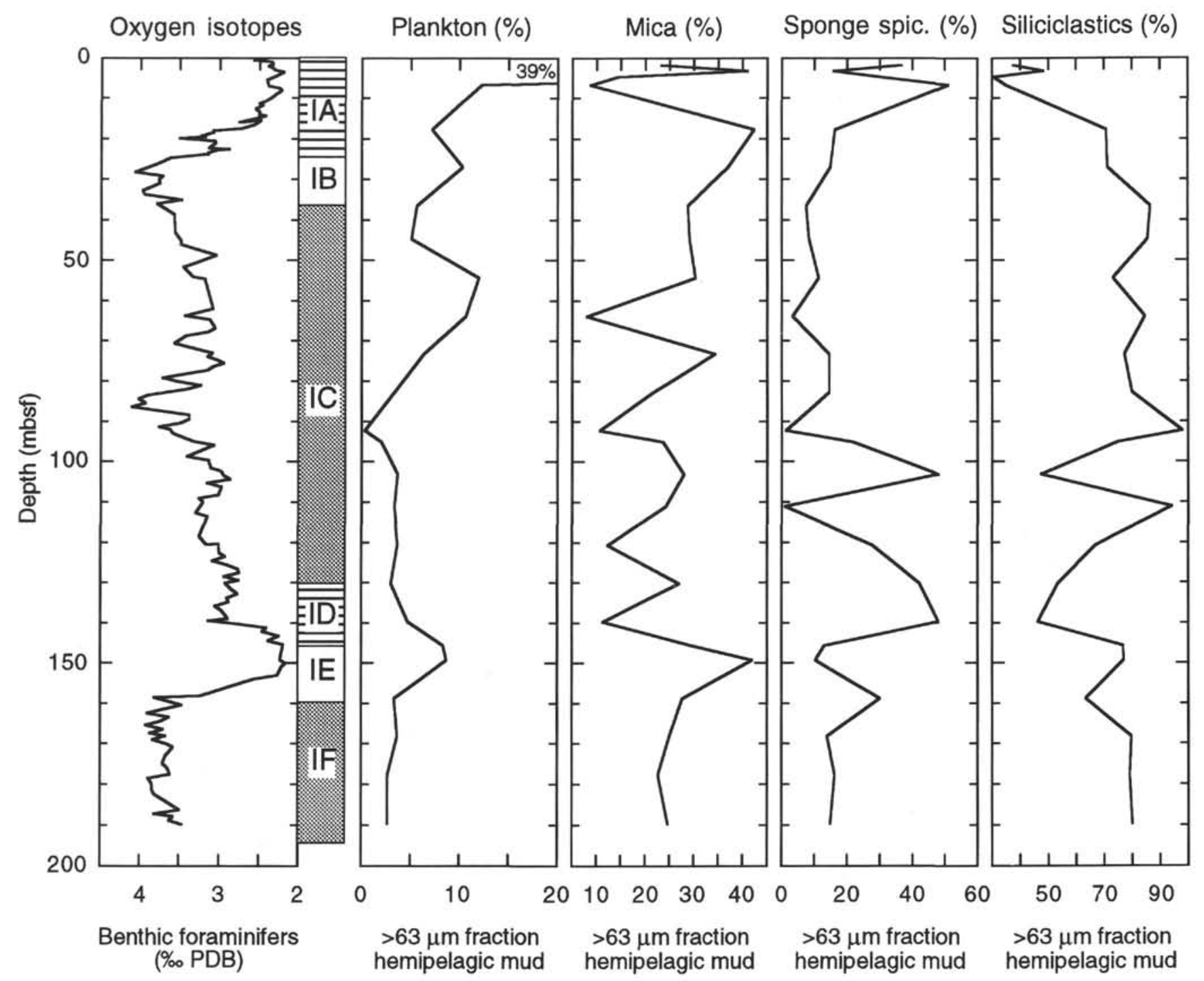

Figure 11. Compositional trends in the sand-sized $(>63 \mu \mathrm{m})$ fraction of hemipelagic mud from Santa Barbara Basin compared with the oxygen isotopic composition of benthic foraminifers at Site 893 (as a proxy for sea-level change). 

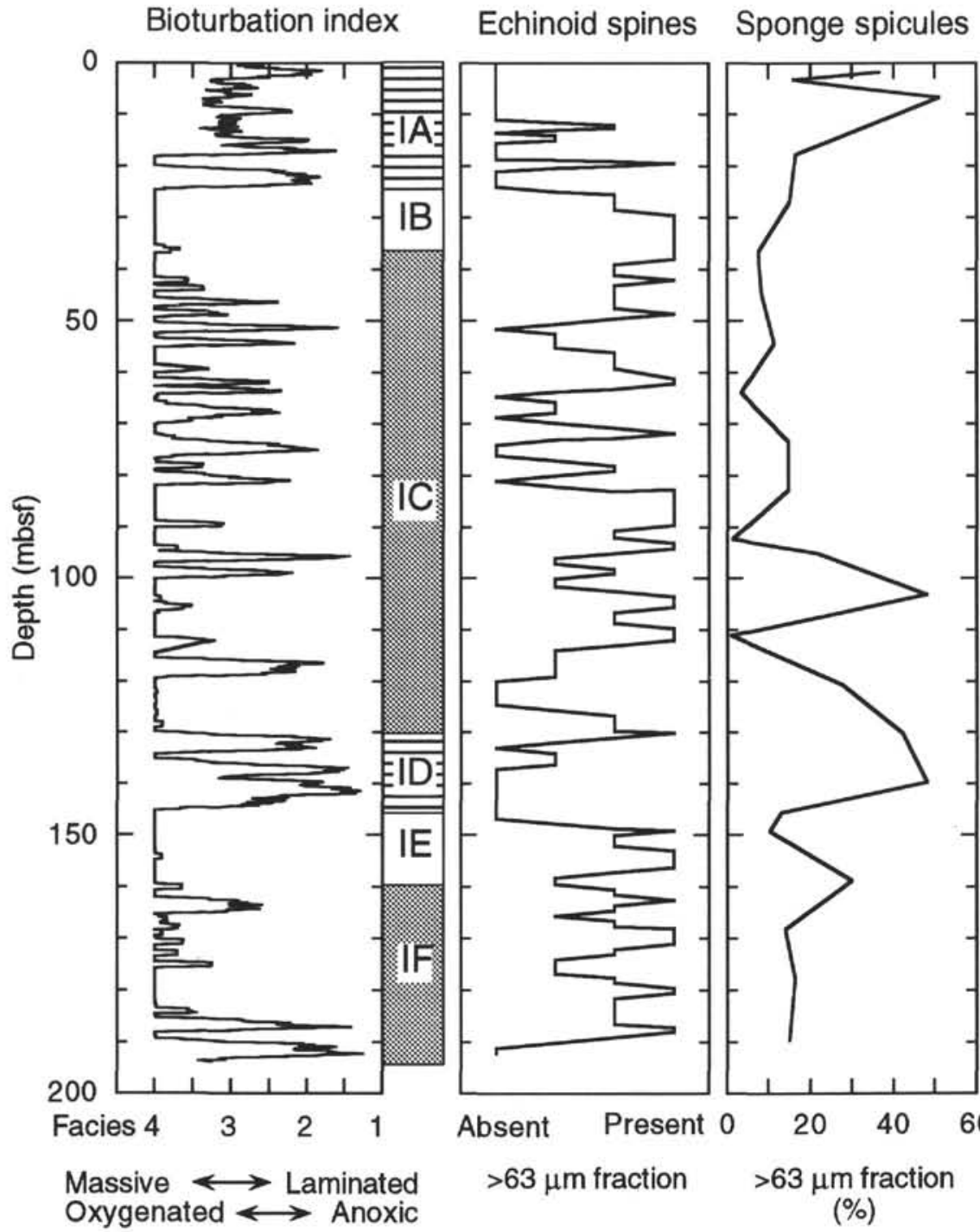

Oxygen isotopes
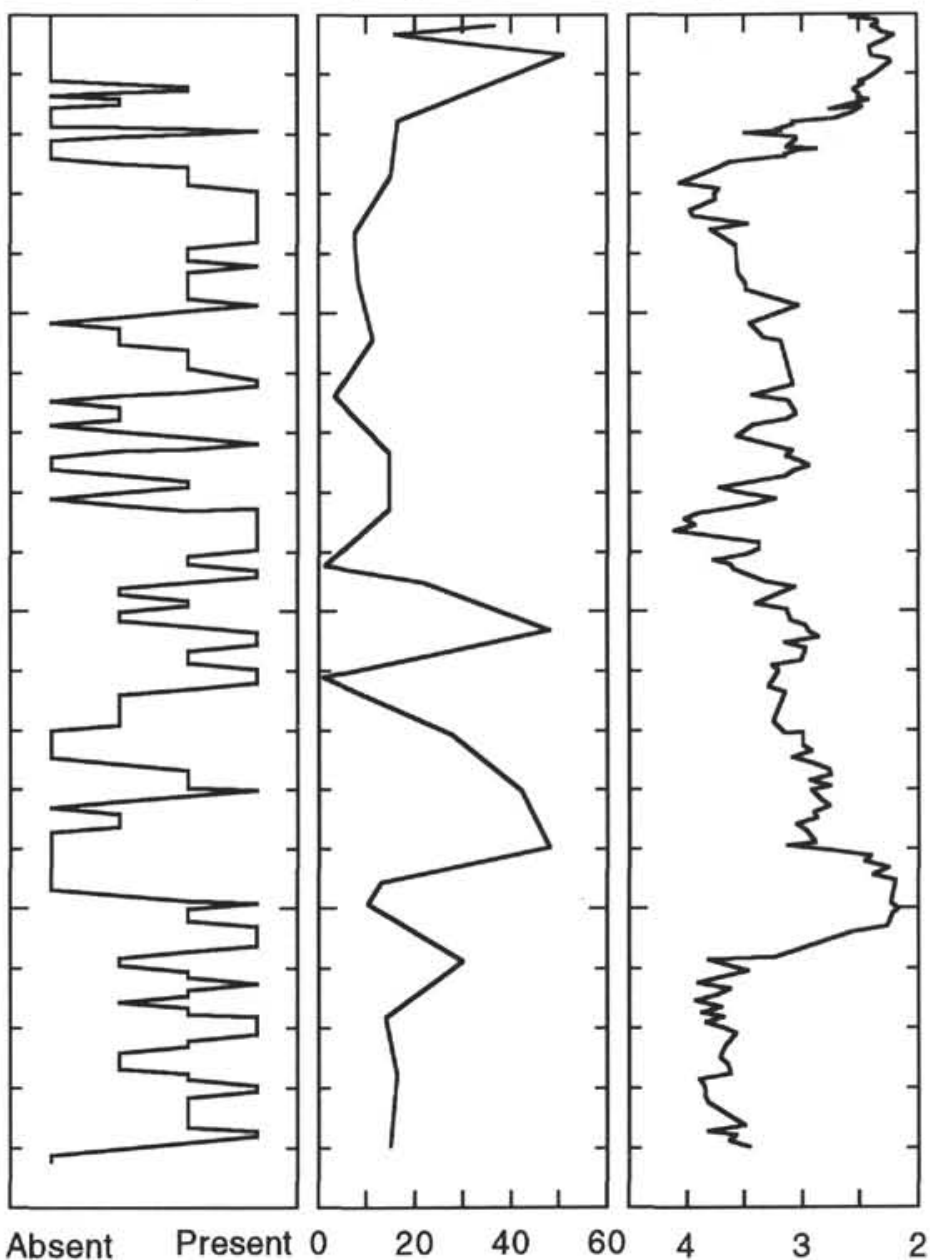

Massive $\longleftrightarrow$ Laminated
Oxygenated $\longleftrightarrow$ Anoxic

$>63 \mu \mathrm{m}$ fraction

$>63 \mu \mathrm{m}$ fraction

(\%)

Benthic foraminifers $(\%$ PDB)

Figure 12. Stratigraphic trends in the presence or absence of echinoid spines and percentage of sponge spicules compared with the oxygenation/bioturbation index and the oxygen isotopic composition of benthic foraminifers from Hole 893A. Echinoid data are smoothed (3-point running average). 
A

Dissolved oxygen $\mathrm{mL} / \mathrm{L}$

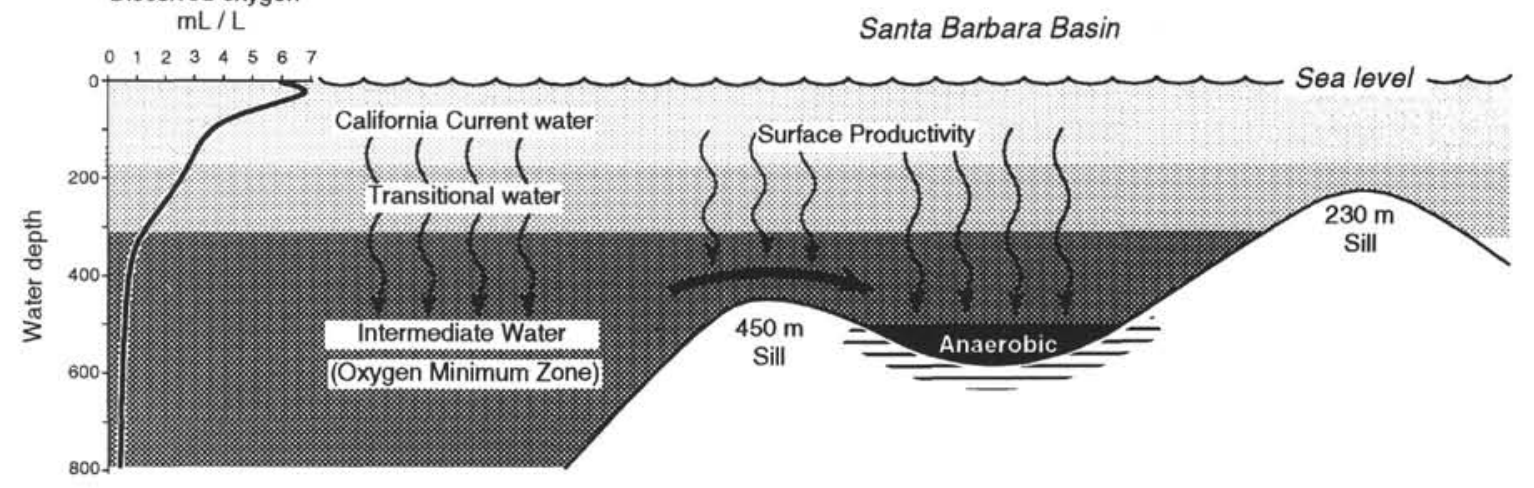

B

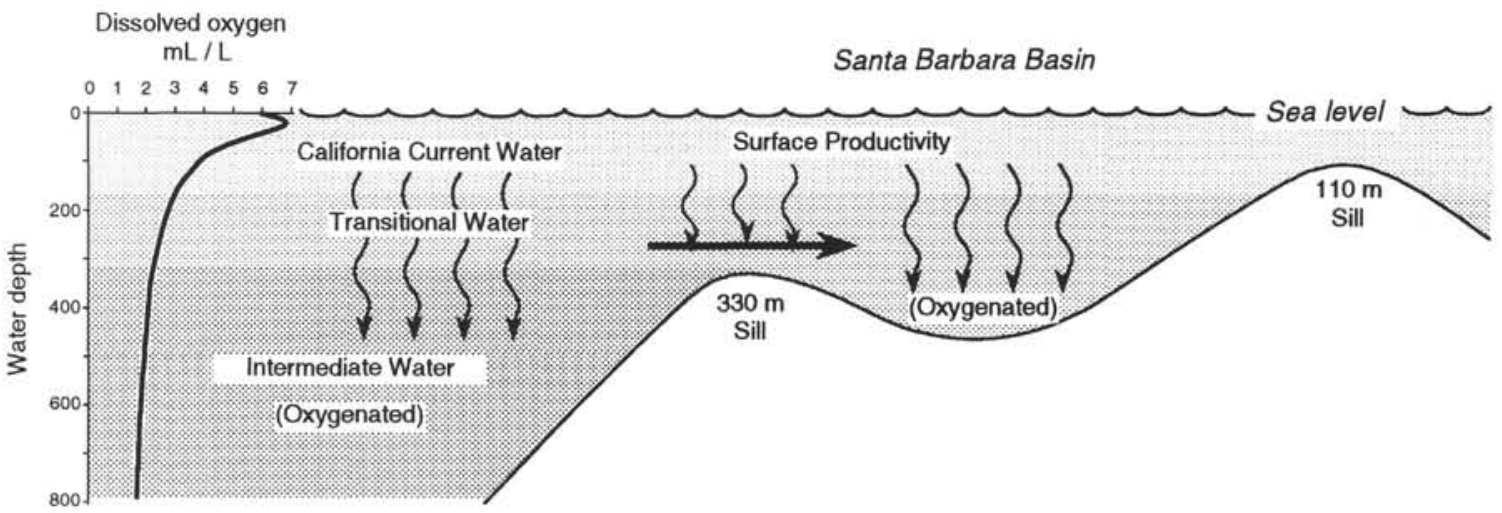

Figure 13. End-member water-mass models explaining oxygenation levels of the Santa Barbara Basin. A. Oxygen-depleted intervals when laminations are preserved at a sea-level highstand. B. Oxygenated intervals when sediments are bioturbated and massive at a sea-level lowstand. Oscillation between basin-oxygenation states generally correlates to, but is not primarily driven by, eustatic variation. Oxygenation of intermediate water is probably the dominant control. See text for discussion. 